\title{
DC-AC POWER SUPPLY FOR BATTERY BASED SYSTEMS
}

\author{
Carlos Elmano de Alencar e Silva, Demercil de Souza Oliveira Júnior, Herminio Miguel Oliveira Filho \\ and Fernando Luiz Marcelo Antunes. \\ Power Processing and Energy Group (GPEC), Federal University of Ceará (UFC). \\ CEP 60.455-760, C.P. 6001, Fortaleza - CE \\ Brazil \\ elmano@dee.ufc.br.
}

\begin{abstract}
This work presents the analysis, design, and experimental development of a single-phase inverter with high frequency transformer isolation and for a wide input voltage range. The high frequency input current ripple is mitigated by the use of a small input $\mathrm{LC}$ filter, and the low frequency current component injected by the inverter is attenuated by the voltage loop controller. The proposed topology can be used in dc voltage-sourced applications such as renewable energy and battery based systems.
\end{abstract}

Keywords - dc-ac conversion, high frequency isolation, wide input voltage range operation.

\section{INTRODUCTION}

The dc-ac converters are particularly one of the most significant and studied class of static power converters. Typical applications are distributed generation, ac motor drives, and battery based systems. Several topologies are available in the literature, which can be classified according to the following characteristics [1]:

- Number of phases: single-phase or three-phase;

- Adjustment of the output voltage;

- Commutation of the switches: hard or soft;

- Presence or absence of isolation transformer;

- Number of power stages.

This work describes the analysis, design, and experimental results of a dc-ac converter that has characteristics such as: single-phase, adjustment of the output voltage, hard commutation of the switches, and high frequency isolation, applied in the implementation of a $400 \mathrm{VA}, 220 \mathrm{Vrms}$, and $400 \mathrm{~Hz}$ power source from a $60-90 \mathrm{Vdc}$ battery input voltage. This equipment is currently operating in the trains of the FEPASA (Ferrovia Paulista S.A., Brazil).

\section{A. Single-Stage Topologies vs. Mutiple-Stage Topologies}

DC-AC converters can be classified in either single-stage or multiple-stage topologies. A single-stage dc-ac converter [2]-[11] is that one that has only one power processing stage, responsible not only for the output voltage adjustment, but also for the sine modulation of the output voltage. A typical example is the dual flyback inverter [7], shown in Figure 1.

Manuscript received on 23/10/2009. Revised on 21/03/2010 and 05/11/2010. Accepted for publication in $16 / 11 / 2010$ by recommendation of the Editor João Onofre P. Pinto.
A multiple-stage dc-ac converter is formed by several converters where each one has a specific function, e.g. output voltage adjustment and/or isolation and/or dc-ac conversion. They can be classified in three types: dc-ac-ac converters [12]-[13] (Figure 2), dc-dc-ac converters [14][20] (Figure 3), or dc-ac-dc-ac converters (Figure 4).

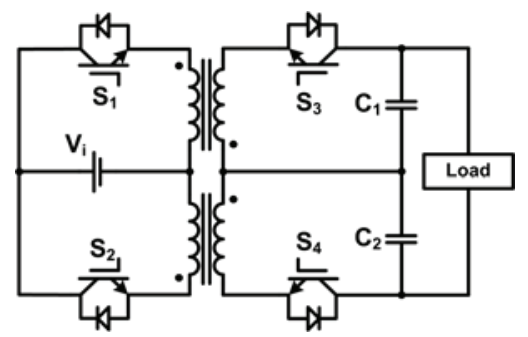

Fig. 1. Dual flyback inverter.

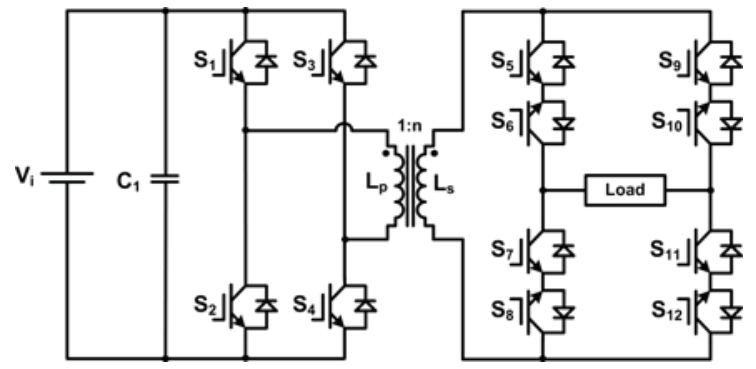

Fig. 2 Example of a dc-ac-ac topology.

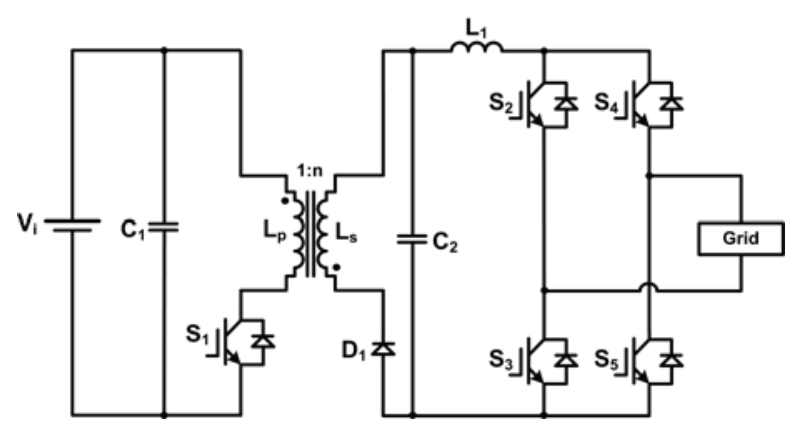

Fig. 3 Example of a dc-dc-ac topology.

Single-stage dc-ac converters are typically used in low power applications [1]. Multiple-stage dc-ac-ac converters possess one high number of semiconductors, reducing the efficiency and increasing the cost. Multiple-stage dc-dc-ac converters have output in current, are applied in grid connected systems. Therefore, these topologies are not the scope of this work, which is focused on dc-ac-dc-ac structures. 


\section{PROPOSED TOPOLOGY}

Figure 4 shows the block diagram representing a dc-ac-dcac system. It is formed by three power stages, as each one of them can be implemented using a classical topology. One is supposed to define which structures must be employed.

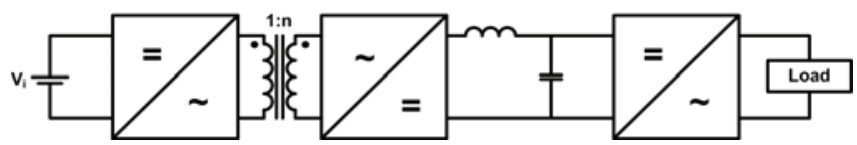

Fig. 4 Block diagram of a dc-ac-dc-ac system.

The complete schematic of proposed topology is shown in Figure 5 .


Fig. 5 Proposed topology.

A classical push-pull converter is used in the first stage, because the switches are not turned on simultaneously, and also due to the intrinsic isolation.

A full-bridge rectifier is chosen in the second stage, due to the absence of central tap and the reduced blocking voltage across the diodes. To further reduce the blocking voltage, two secondary windings are employed in the transformer of the push-pull converter.

The third stage is composed by a full-bridge inverter, once that a push-pull arrangement would require an additional low frequency transformer. A half-bridge topology is not adequate as well, due to the doubled input voltage.

Three LC filters are employed. The first one is placed between the primary voltage source and the first stage, in order to assure reduced high frequency ripple of the input current. The second one is placed between the second and third stages, to provide the dc voltage link to the full-bridge inverter and also mitigate high frequency current flow through the previous stages. The last filter is placed in the load side.

A dissipative RCD snubber is employed in the switches of the push-pull converter to preserve the semiconductor devices due to eventual voltage overshoot caused by the leakage inductance of the high frequency transformer.

\section{DESIGN PROCEDURE}

The prototype specifications and design assumptions are shown in Table I.

TABLE I

Prototype Specifications and Design Assumptions

\begin{tabular}{cc}
\hline Parameter & Specification \\
\hline Input voltage range & $\mathrm{V}_{\mathrm{i}}=60-90 \mathrm{~V}$ \\
\hline Rms output voltage & $\mathrm{V}_{\mathrm{o}}=220 \mathrm{~V}_{\mathrm{rms}}+/-5 \%$ \\
\hline Maximum output voltage THD & $<5 \%$ \\
\hline Apparent power & $\mathrm{S}_{\mathrm{o}}=400 \mathrm{VA}$ \\
\hline Load power factor & $\mathrm{PF}=1$ \\
\hline Output fundamental frequency & $\mathrm{f}_{\mathrm{r}}=400 \mathrm{~Hz}$ \\
\hline Modulation index & $\mathrm{Ma}^{2}=0.75$ \\
\hline Maximum input current ripple & $\Delta \mathrm{I}_{\mathrm{i}}=6 \%$ \\
\hline Maximum input voltage ripple & $\Delta \mathrm{V}_{\mathrm{i}}=3 \mathrm{~V}$ \\
\hline Efficiency (push-pull converter) & $\eta_{1}=0.9$ \\
\hline Efficiency (full-bridge converter) & $\eta_{2}=0.9$ \\
\hline Switching frequency (push-pull converter) & $\mathrm{f}_{1}=40 \mathrm{kHz}$ \\
\hline Switching frequency (full-bridge converter) & $\mathrm{f}_{2}=40 \mathrm{kHz}$ \\
\hline
\end{tabular}

\section{A. Power Circuit Design}

The peak value of output voltage $\left(\mathrm{V}_{\mathrm{o} \_\mathrm{pk}}\right)$ is given by (1).

$$
V_{o_{-} p k}=\sqrt{2} \cdot V_{o} \rightarrow V_{o_{-} p k} \cong 311 V
$$

The input voltage of third stage $\left(\mathrm{V}_{\mathrm{r}}\right)$ is given by (2).

$$
V_{r}=\frac{V_{o_{-} p k}}{M_{a}} \rightarrow V_{r} \cong 420 \mathrm{~V}
$$

Considering the maximum duty cycle in the push-pull converter equal to 0.45 , the minimum turns ratio (n) is given by (3).

$$
n>\frac{V_{r}}{2 \cdot D_{\max } \cdot V_{i_{-} \min }} \rightarrow n>7.78
$$

By convenience, the transformer turns ratio is chosen:

$$
n=8
$$

Thus the minimum duty cycle $\left(\mathrm{D}_{\min }\right)$ in the push-pull converter is given by (5).

$$
D_{\text {min }}=\frac{V_{r}}{2 \cdot n \cdot V_{i_{-} \max }} \rightarrow D_{\text {min }} \cong 0.29
$$

The peak current drained by the push-pull converter is given by (6).

$$
I_{s h_{-} p k}=\frac{S_{o} \cdot P F \cdot n}{\eta_{1} \cdot \eta_{2} \cdot V_{r}} \rightarrow I_{s h_{-} p k} \cong 9.52 \mathrm{~A}
$$

The maximum and minimum average currents through the primary voltage source $\left(\mathrm{I}_{\mathrm{i}_{-} \max }\right.$ and $\mathrm{I}_{\mathrm{i}_{\text {_min }}}$, respectively) are given by (7) and (8), respectively. 


$$
\begin{aligned}
& I_{i_{-} \max }=\frac{S_{o} \cdot P F}{\eta_{1} \cdot \eta_{2} \cdot V_{i_{-} \min }} \rightarrow I_{i_{-} \max } \cong 8.33 \mathrm{~A} \\
& I_{i_{-} \min }=\frac{S_{o} \cdot P F}{\eta_{1} \cdot \eta_{2} \cdot V_{i_{-} \max }} \rightarrow I_{i_{-} \min } \cong 5.56 \mathrm{~A}
\end{aligned}
$$

The rms current through filter capacitor $\mathrm{C}_{1}$ is given by (9).

$$
\begin{aligned}
& I_{C 1_{-} r m s}=I_{s h+p k} \cdot \sqrt{2 \cdot D_{\min } \cdot\left(1-2 \cdot D_{\min }\right)} \\
& \rightarrow I_{C 1_{-} r m s} \cong 4.7 \mathrm{~A}
\end{aligned}
$$

The maximum equivalent series resistance of capacitor $\mathrm{C}_{1}$ $\left(\mathrm{R}_{\mathrm{Cl}}\right)$ is given by $(10)$.

$$
R_{C 1}<\frac{\Delta V_{i}}{I_{s h_{-} p k}} \rightarrow R_{C 1}<315 \mathrm{~m} \Omega
$$

The filter inductance $\left(\mathrm{L}_{1}\right)$ is given by (11).

$$
L_{1}=\frac{\Delta V_{i} \cdot D_{\max }}{\Delta I_{i} \cdot I_{i_{-} \min } \cdot f_{1}} \rightarrow L_{1}=100 \mu \mathrm{H}
$$

The rms value current through capacitor $\mathrm{C}_{2}$ is obtained by simulation and given by (12).

$$
I_{C 2 \_r m s} \cong 2 \mathrm{~A}
$$

The peak output current $\left(I_{o p k}\right)$ is given by (13).

$$
I_{o_{-} p k}=\sqrt{2} \cdot \frac{S_{o} \cdot P F}{V_{o}}
$$

Considering the voltage ripple across $\mathrm{C}_{2}$ as $1 \%$ of $\mathrm{V}_{\mathrm{r}}$, the maximum equivalent series resistance of $\mathrm{C}_{2}\left(\mathrm{R}_{\mathrm{C} 2}\right)$ is given by (14).

$$
R_{C 2}<\frac{0.01 \cdot V_{r}}{I_{o_{-} p k}} \rightarrow R_{C 2}<1.6 \Omega
$$

The cut-off frequency of the second filter $\left(f_{\mathrm{f} 2}\right)$ must be established so that the components from $800 \mathrm{~Hz}$ the input current inverter are blocked and allow a reasonable inductor filter size. For the given example this frequency is defined as $110 \mathrm{~Hz}$ and then inductance $\mathrm{L}_{2}$ is given by (15).

$$
L_{2}=\frac{1}{\left(2 \cdot \pi \cdot f_{f 2}\right)^{2} \cdot C_{2}} \rightarrow L_{2}=21 m H
$$

Considering the current ripple through inductor $\mathrm{L}_{3}$ as $35 \%$ of $\mathrm{I}_{\mathrm{o}-\mathrm{pk}}$, the respective inductance is given by (16).

$$
L_{3}=\frac{\left(V_{r}-\sqrt{2} \cdot V_{o}\right) \cdot M_{a}}{0.35 \cdot I_{o_{-} p k}} \rightarrow L_{3}=2.27 \mathrm{mH}
$$

In order to get a cut-off frequency around $4 \mathrm{kHz}$ in the third filter, filter capacitance $\mathrm{C}_{3}$ can be obtained from (17).

$$
C_{3}=\frac{1}{\left(2 \cdot \pi \cdot f_{f 3}\right)^{2} \cdot L_{3}} \rightarrow C_{3} \cong 700 n F
$$

Table II lists the components used in the prototype.

TABLE II

Components List

\begin{tabular}{cc}
\hline Reference & Component \\
\hline $\mathrm{C}_{1}$ & $470 \mathrm{uF} / 250 \mathrm{Vdc}$ \\
\hline $\mathrm{C}_{2}$ & $100 \mathrm{uF} / 450 \mathrm{Vdc}$ \\
\hline $\mathrm{C}_{3}$ & $1 \mathrm{uF} / 250 \mathrm{Vac}$ \\
\hline $\mathrm{C}_{\mathrm{s} 1}$ and $\mathrm{C}_{\mathrm{s} 2}$ & $1 \mathrm{nF} / 400 \mathrm{Vdc}$ \\
\hline $\mathrm{D}_{\mathrm{s} 1}$ and $\mathrm{D}_{\mathrm{s} 2}$ & $\mathrm{MUR} 240$ \\
\hline $\mathrm{D}_{1}$ to $\mathrm{D}_{6}$ & $\mathrm{MUR} 1100$ \\
\hline $\mathrm{L}_{1}$ & $100 \mu \mathrm{H} / 8.5 \mathrm{~A}$ \\
\hline $\mathrm{L}_{2}$ & $21 \mathrm{mH} / 1.1 \mathrm{~A}$ \\
\hline $\mathrm{L}_{3}$ & $2.27 \mathrm{mH} / 1.8 \mathrm{~A}$ \\
\hline $\mathrm{R}_{\mathrm{s} 1}$ and $\mathrm{R}_{\mathrm{s} 2}$ & $100 \Omega / 3 \mathrm{~W}$ \\
\hline $\mathrm{S}_{1}$ and $\mathrm{S}_{2}$ & $\mathrm{IRFP} 460 \mathrm{~A}$ \\
\hline $\mathrm{S}_{3}$ to $\mathrm{S}_{6}$ & IRGB20B60PD1 \\
\hline
\end{tabular}

\section{B. DC-AC-DC Control Loop Design}

The dc-ac-dc converter can be modeled by a buck converter, as shown in Figure 6.

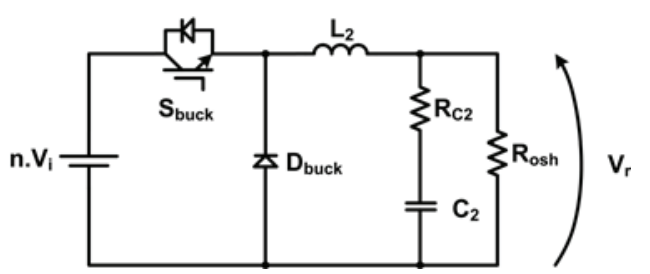

Fig. 6 Equivalent circuit modeling of the dc-ac-dc converter.

The transfer function (TF) of the dc-ac-dc converter is shown in (18) and its Bode diagram is shown in Figure 7.

$$
G_{s h}(s)=k_{d} \cdot \frac{s+\frac{1}{\omega_{z s h}}}{\frac{1}{\omega_{o s h}^{2}} \cdot s^{2}+\frac{1}{\omega_{o s h} \cdot Q_{s h}} \cdot s+1}
$$

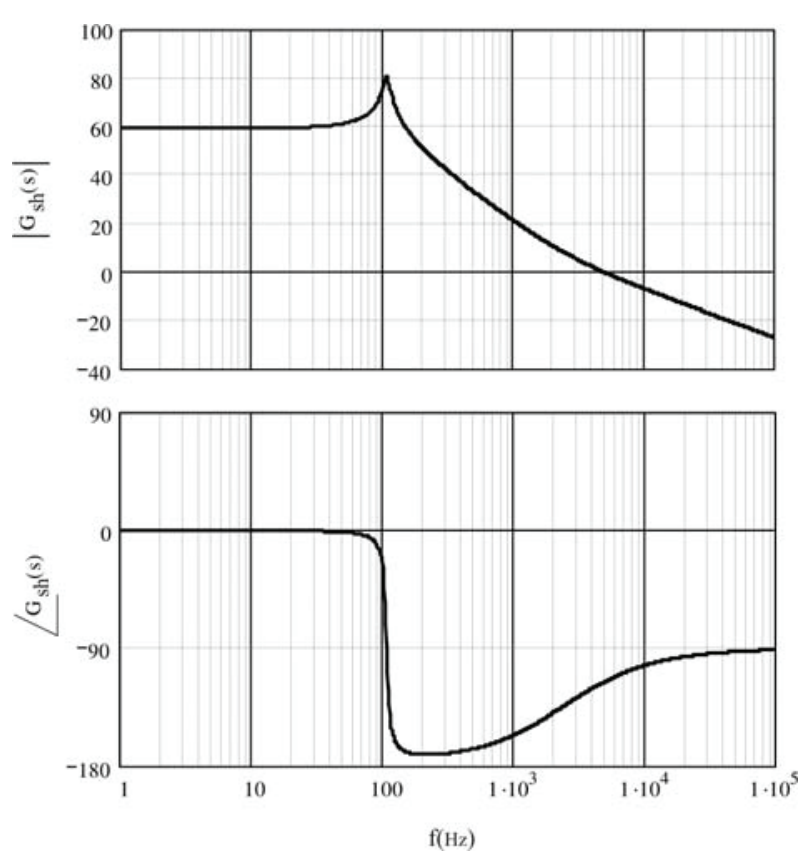

Fig. 7 Bode diagram of Gsh(s). 
Where,

$$
\begin{gathered}
K_{d}=n \cdot V_{i_{-} \max } \rightarrow K_{d}=720 \\
\omega_{z s h}=\frac{1}{C_{2} \cdot R_{C 2}} \rightarrow \omega_{z s h}=14930 \mathrm{rad} / \mathrm{s} \\
\omega_{o s h}=\frac{1}{\sqrt{L_{2} \cdot C_{2}}} \cdot \sqrt{\frac{R_{o s h}}{R_{o s h}+R_{C 2}}} \rightarrow \omega_{o s h}=673.64 \mathrm{rad} / \mathrm{s} \\
R_{o s h}=\frac{V_{r} \cdot \eta_{2}}{P_{o}} \rightarrow R_{o s h}=400 \Omega \\
Q_{s h}=\frac{\sqrt{L_{2} \cdot C_{2} \cdot R_{o s h} \cdot\left(R_{o s h}+R_{C 2}\right)}}{C_{2} \cdot R_{o s h} \cdot R_{C 2}+L_{2}} \rightarrow Q_{s h}=12.17
\end{gathered}
$$

The open loop TF $\mathrm{G}_{\mathrm{sh}}(\mathrm{s})$ is given by (24).

$$
F T L A_{s h}(s)=G_{s h}(s) \cdot F_{m} \cdot H_{s h}(s)
$$

Where $\mathrm{H}_{\mathrm{sh}}(\mathrm{s})$ is the feedback TF and $\mathrm{F}_{\mathrm{m}}$ is the modulator gain:

$$
\begin{gathered}
H_{s h}(s)=\frac{V_{r e f}}{V_{r}} \rightarrow H(s)=5.95 \times 10^{-3} \\
F_{m}=\frac{1}{V_{r e f}} \rightarrow F_{m}=0.4
\end{gathered}
$$

As the control goals are null steady state error and the mitigation of the low frequency ripple of the current through the inverter, a simple PID controller, shown in Figure 8, can be used.

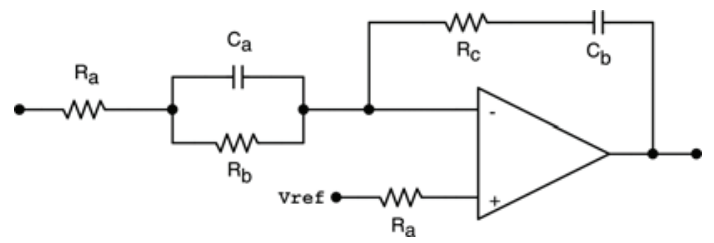

Fig. 8 DC-AC-DC controller.

The zeros of the controller match with the poles of the system, the pole in $\omega_{\text {zsh }}$ of the controller match with the zero of the system, and an additional pole added at the origin establishes null error in the steady state. The dc-ac-dc converter controller TF is given by (27).

$$
C_{s h}(s)=K_{v s h} \cdot \frac{\left(s+\omega_{o s h}\right) \cdot\left(s+\omega_{o s h}\right)}{s \cdot\left(s+\omega_{z s h}\right)}
$$

The gain $\mathrm{K}_{\mathrm{vsh}}$ must establish a crossing frequency $\left(\mathrm{f}_{\mathrm{csh}}\right)$ about $150 \mathrm{~Hz}$, in order to attenuate the $800 \mathrm{~Hz}$ current ripple. Then, the $\mathrm{K}_{\mathrm{vsh}}$ value é dado by (28).

$$
K_{v s h}=\frac{1}{F T L A_{s h}\left(2 \cdot \pi \cdot f_{c s h}\right) \cdot T_{s h}\left(2 \cdot \pi \cdot f_{c s h}\right)}
$$

Where,

$$
T_{s h}(s)=\frac{\left(s+\omega_{o s h}\right) \cdot\left(s+\omega_{o s h}\right)}{s \cdot\left(s+\omega_{z s h}\right)}
$$

Then,

$$
K_{v s h}=5.6
$$

Deciding the value of the $R_{a}$ in $1 \mathrm{k} \Omega$, the controller components can be obtained from expressions (31) to (34).

$$
\begin{gathered}
R_{c}=K_{v s h} \cdot R_{a} \rightarrow R_{c}=5.6 \mathrm{k} \Omega \\
C_{b}=\frac{1}{\omega_{\text {osh }} \cdot R_{c}} \rightarrow C_{b}=270 \mathrm{nF} \\
R_{b}=R_{a} \cdot\left(\frac{\omega_{z s h}}{\omega_{o s h}}-1\right) \rightarrow R_{b}=22 \mathrm{k} \Omega \\
C_{a}=\frac{1}{\omega_{\text {osh }} \cdot R_{b}} \rightarrow C_{a}=68 \mathrm{nF}
\end{gathered}
$$

The Bode diagram of the resulting transfer function of the compensated system is shown in Figure 9.

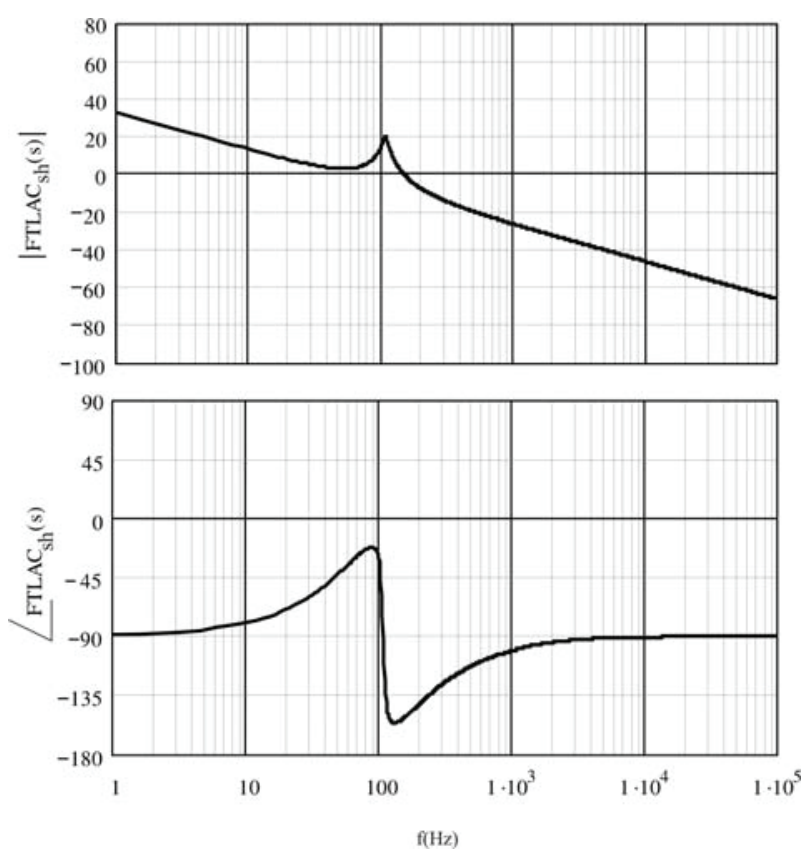

Fig. 9 Bode diagram of FTLACsh(s).

Figure 10 shows the block diagram of the dc-ac-dc stage control.

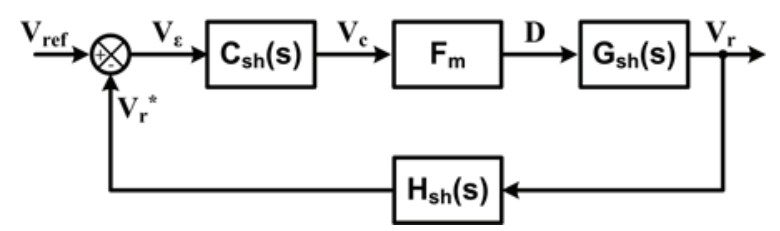

Fig. 10 Block diagram of he dc-ac-dc control. 


\section{Inverter Control Loop Design}

The TF of the dc-ac converter is given by (35).

$$
G_{f b}(s)=V_{r} \cdot \frac{1}{L_{3} \cdot C_{3} \cdot s^{2}+\frac{L_{3}}{R_{o}} \cdot s+1}
$$

Where, nominal output resistance $\left(\mathrm{R}_{\mathrm{o}}\right)$ of the inverter is give by (36).

$$
R_{o}=\frac{V_{o}^{2}}{S_{o} \cdot P F}
$$

The feedback gain and the modulator gain are given by (37) and (38), respectively.

$$
\begin{gathered}
H_{f b}(s)=\frac{1}{100} \\
F_{m}=\frac{1}{V_{r e f}} \rightarrow F_{m}=0.4
\end{gathered}
$$

The open loop TF of the $\mathrm{G}_{\mathrm{fb}}(\mathrm{s})$ is given by (39).

$$
F T L A_{f b}(s)=G_{f b}(s) \cdot F_{m} \cdot H_{f b}(s)
$$

The Bode diagram of the FTLA $_{\mathrm{fb}}(\mathrm{s})$ is shown in Figure 11.
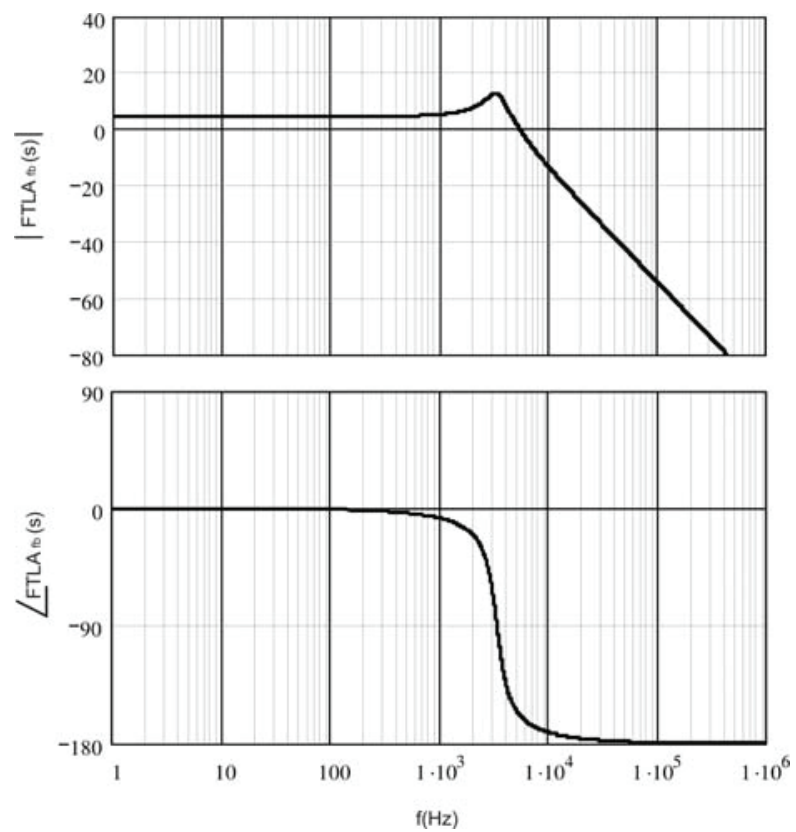

Fig. 11 Bode diagram of FTLAfb(s).

As the control goals are null steady state error and to assure one high speed response, the PID controller shown in Figure 12 can be used.

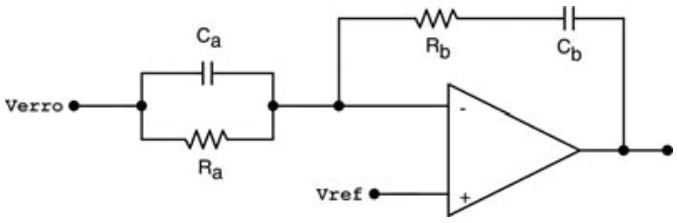

Fig. 12 Inverter controller.

The zeros of the controller match with the poles of the system, and an additional pole added at the origin establishes null error in the steady state. The inverter controller TF is given by (40).

$$
C_{f b}(s)=K_{v f b} \cdot \frac{\left(s+\omega_{o f b}\right) \cdot\left(s+\omega_{o f b}\right)}{s}
$$

Establishing the crossing frequency as $8 \mathrm{kHz}$, the controller gain $\mathrm{K}_{\mathrm{vfb}}$ is given by (41).

$$
K_{v f b}=37 \times 10^{3}
$$

By choosing $\mathrm{R}_{\mathrm{a}}=470 \mathrm{k} \Omega$, the controller components can be obtained from expressions (42) to (44).

$$
\begin{gathered}
C_{a}=\frac{1}{\omega_{o f b} \cdot R_{a}} \rightarrow C_{a}=110 p F \\
C_{b}=\frac{1}{K_{v} \cdot R_{a}} \rightarrow C_{b}=22 n F
\end{gathered}
$$

$$
R_{b}=\frac{1}{\omega_{o f b} \cdot C_{b}} \rightarrow R_{b}=2.2 \mathrm{k} \Omega
$$

Then, the Bode diagram of the open loop system with the designed controller FTLAC $\mathrm{fb}_{\mathrm{fb}}(\mathrm{s})$ is shown in Figure 13.
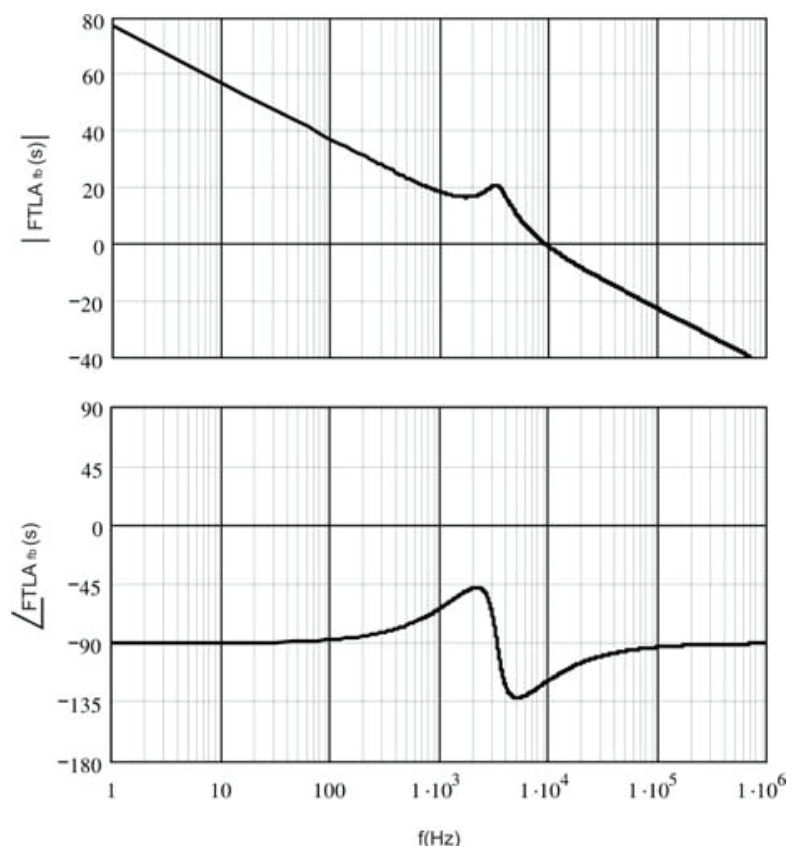

Fig. 13 Bode diagram of FTLACfb(s).

Figure 14 shows the block diagram of the dc-ac-dc stage control.

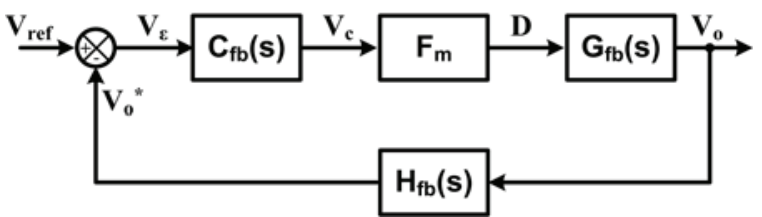

Fig. 14 Block diagram of the inverter control. 


\section{EXPERIMENTAL RESULTS}

Some experimental results are presented in this section. In Figure 15 one can see a low input current ripple through inductor $\mathrm{L}_{1}$ and low voltage ripple across capacitor $\mathrm{C}_{1}$.

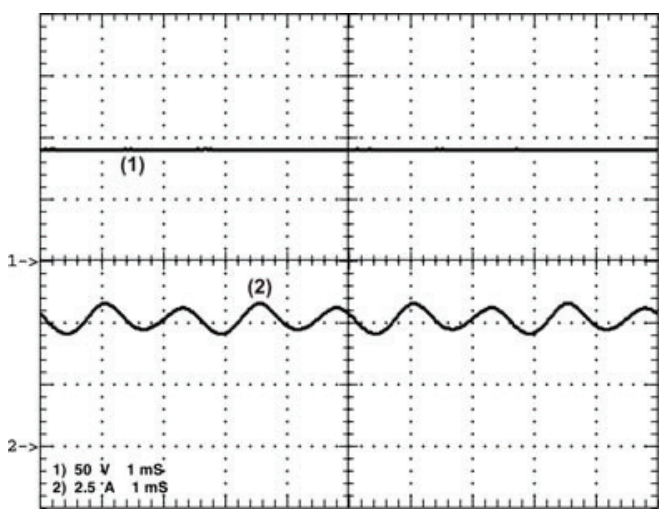

Fig. 15 Voltage ripple across the filter capacitor $C_{1}(1-50 \mathrm{~V} / \mathrm{div})$ and current ripple across the filter inductor $\mathrm{L}_{1}(2-2.5 \mathrm{~A} / \mathrm{div})$.

Figure 16 shows the voltage and the current across the switches of the push-pull stage. The voltage across the switches of the push-pull stage does not contain considerable voltage peaks and stresses. The current waveform presents some oscillation due to the reverse recovery of the output diodes, but it is considered acceptable.

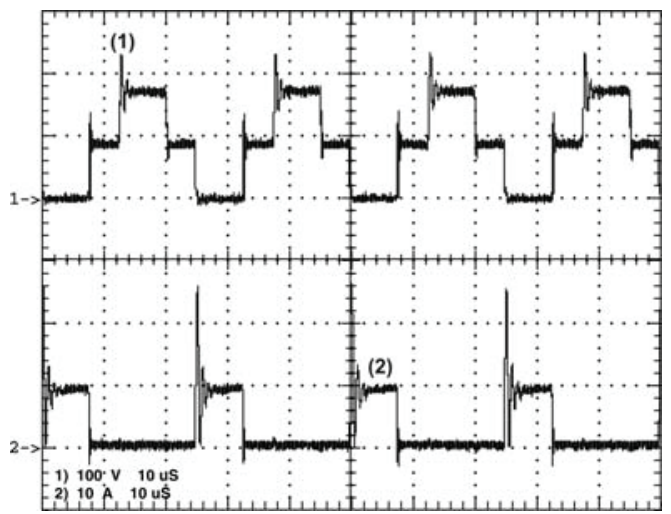

Fig. 16 Voltage across the switch in the push-pull $(1-100 \mathrm{~V} / \mathrm{div}-$ 10us) and current through the primary winding of push-pull transformer $(2-10 \mathrm{~A} / \mathrm{div}-10 \mathrm{us})$.

The Figure 17 shows the input current drained by the inverter for full linear load.

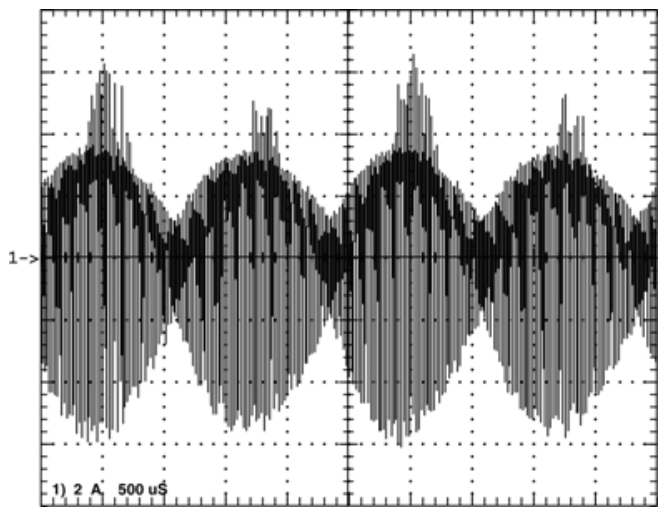

Fig. 17 Input current waveform of the inverter (2A/div - 500us).
Comparing Figure 17 with the Figure 15, it can be seen that the low frequency ripple is attenuated in $\mathrm{L}_{1}$ current, due to the voltage loop and the filter formed by $\mathrm{L}_{2}$ and $\mathrm{C}_{2}$. Figure 18 shows the inverter output voltage and also the current through output inductor $\mathrm{L}_{3}$, both for full linear load.

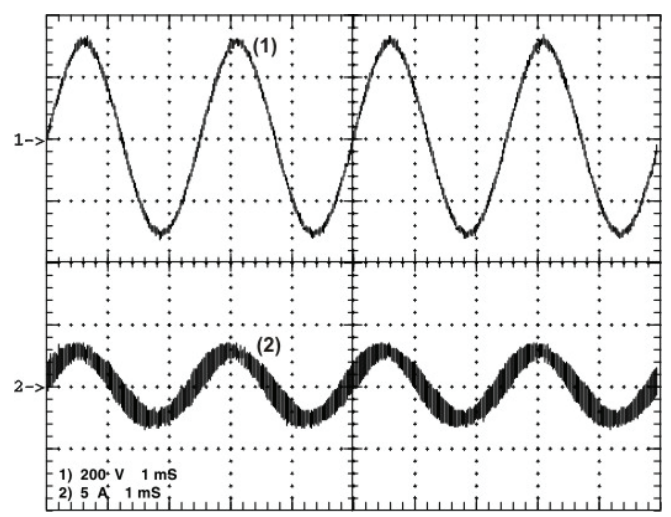

Fig. 18 Output voltage $(1-200 \mathrm{~V} / \mathrm{div}-1 \mathrm{~ms})$ and current through the filter inductor $(2-5 \mathrm{~A} / \mathrm{div}-1 \mathrm{~ms})$.

In Figure 19 one can see the harmonic spectrum of the output voltage for full linear load and the total harmonic distortion (THD) is about $2.5 \%$.

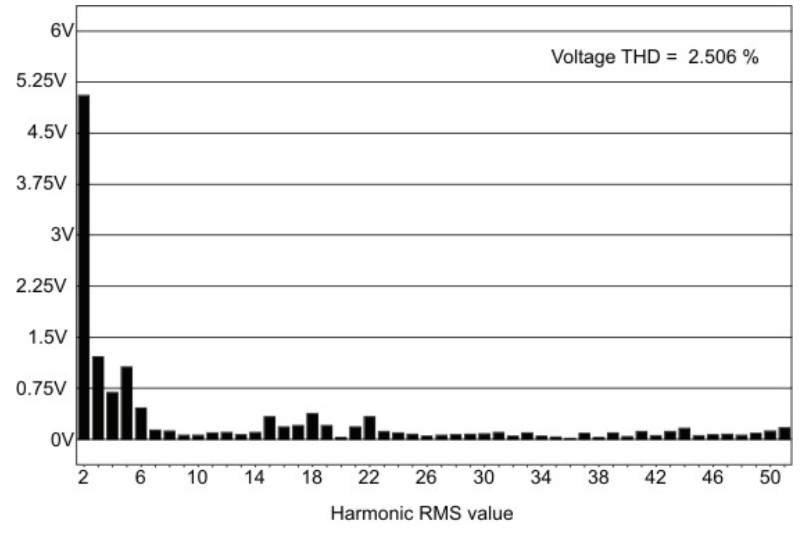

Fig. 19 Harmonic spectrum and THD of the output voltage for full linear load.

Figure 20 shows the output voltage and current through the filter inductor $\mathrm{L}_{3}$ for a load step of the $10 \%$ for $100 \%$ of the rated load. It can be seen an optimum load step response.

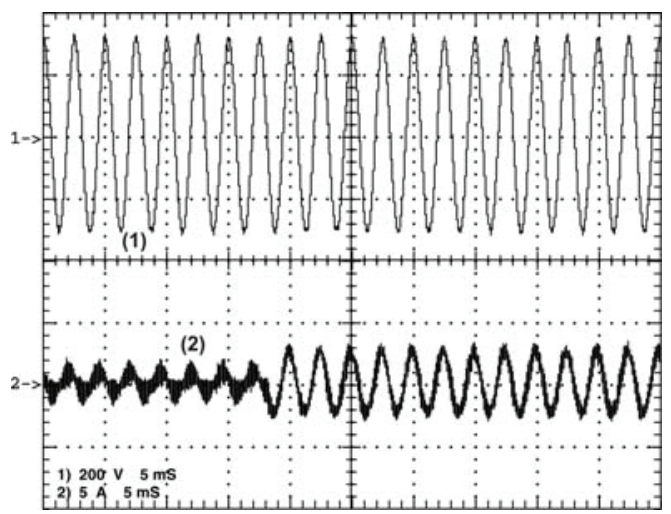

Fig. 20 Output voltage $(1-200 \mathrm{~V} / \mathrm{div}-5 \mathrm{~ms})$ and current through the filter inductor $\mathrm{L}_{3}(2-5 \mathrm{~A} / \mathrm{div}-5 \mathrm{~ms})$ for a load step of the $10 \%$ to $100 \%$ of the rated power. 
Figure 21 shows the output voltage and load current for a nonlinear load.

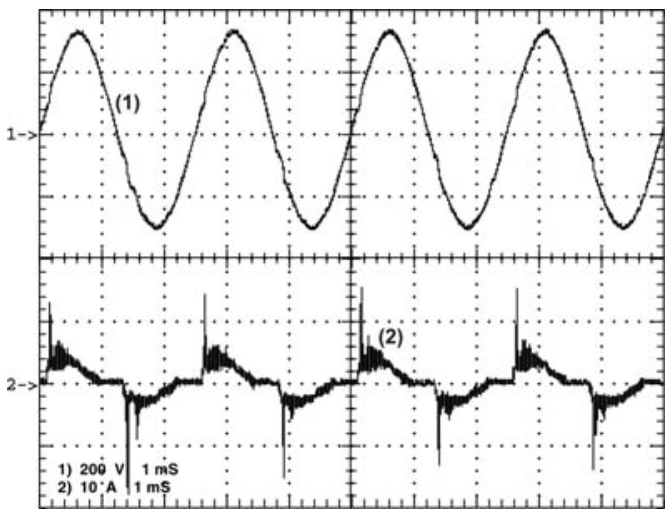

Fig. 21 Output voltage $(1-200 \mathrm{~V} / \mathrm{div}-1 \mathrm{~ms})$ and load current $(2-$ $10 \mathrm{~A} / \mathrm{div}-1 \mathrm{~ms}$ ) for nonlinear load.

The harmonic spectrum and THD of the output voltage for non-linear load is shown in Figure 22. The total harmonic distortion is about $3 \%$.

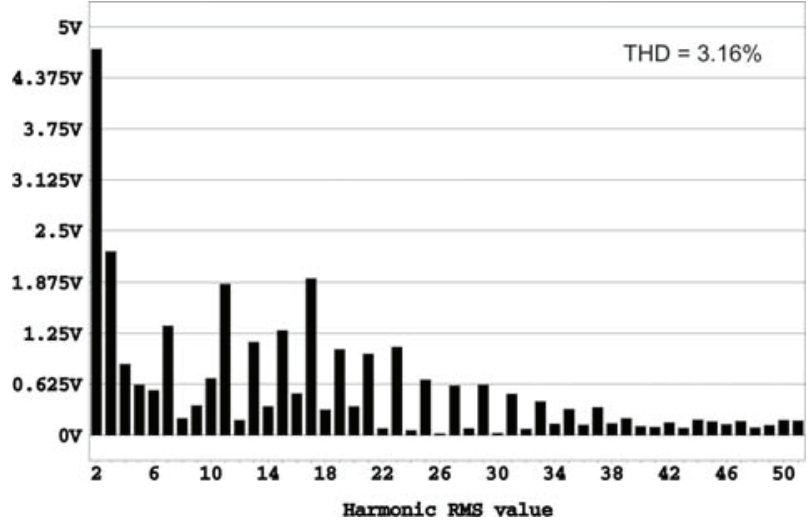

Fig. 22 Harmonic spectrum and THD of the output voltage for nonlinear load.

In Figure 23 one can see the obtained global efficiency curve. The efficiency is greater than the specified.

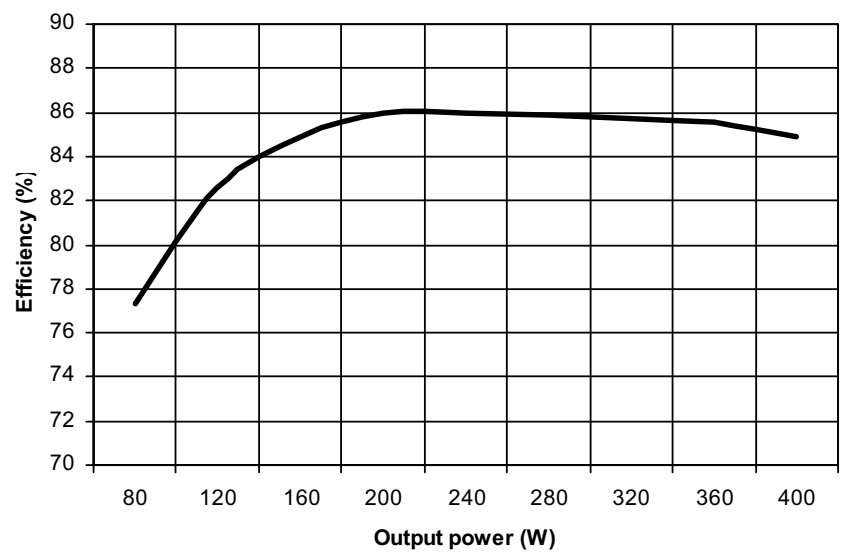

Fig. 23 Global efficiency curve.
In Figure 24 one can see the commercial prototype developed.

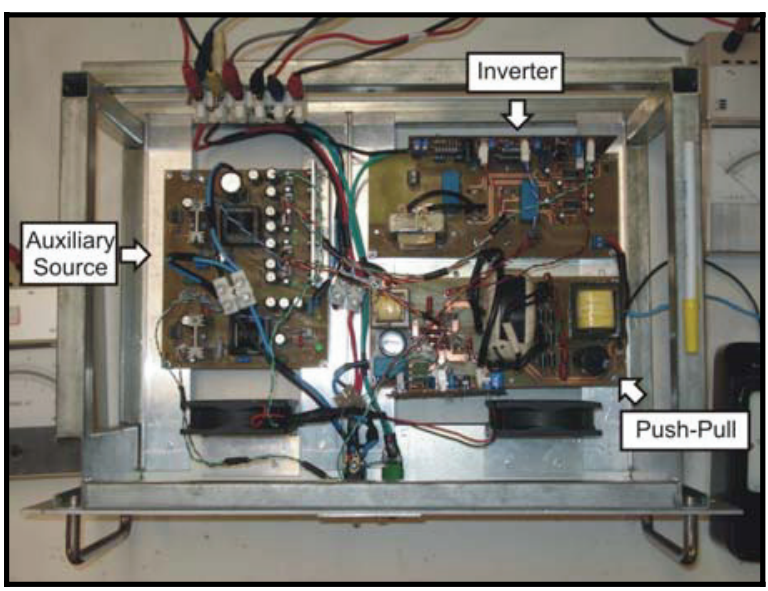

Fig. 24 Prototype picture.

\section{CONCLUSION}

This paper has presented a topology feasible for dc voltage sourced systems, where small input current ripple is necessary and high input voltage range exists. The low frequency component of the current injected by the inverter is attenuated by the LC output filter of the push-pull converter and by the design of the respective voltage loop controller.

The work has been supported by experimental results showing the low input current ripple, low output voltage THD and high efficiency. This equipment is currently operating in the trains of the FEPASA (Ferrovia Paulista S.A., Brazil).

\section{ACKNOWLEDGEMENTS}

The authors would like to thank FUNCAP, CNPq and CAPES for the financial support and incentive the scientific research.

\section{REFERENCES}

[1] Y. Xue, L. Chang, S.B. Kjaer, J. Bordonau, T. Shimizu, "Topologies of single-phase inverters for small distributed power generators: an overview", IEEE Transactions on Power Electronics, vol. 19, no. 5, pp. 1305-1314, September 2004.

[2] R. O. Cáceres and I. Barbi, "A boost dc-ac converter: analysis, design, and experimentation", IEEE Transactions on Power Electronics, vol. 14, no. 1, pp. 134-141, January 1999.

[3] N. Vázquez, J. Almazan, J. Álvarez, C. Aguilar, J. Arau, "Analysis and experimental study of the buck, boost and buck-boost inverters", in Proc. of IEEE PESC'99, vol. 2, pp. 801-806, 1999.

[4] N. Kasa, T. Iida, H. Iwamoto, “An inverter using buckboost type chopper circuits for popular small-scale photovoltaic power system", in Proc. of IEEE IECON'99, vol. 1, pp. 185-190, 1999. 
[5] M. Kusakawa, H. Nagayoshi, K. Kamisako, K. Kurokawa, "Further improvement of a transformerless, voltage-boosting inverter for ac modules", Solar Energy Materials and Solar Cells, vol. 67, no. 1-4, pp. 379-387, March 2001.

[6] C.M. Wang, "A novel single-stage full-bridge buckboost inverter", in Proc. of IEEE APEC'03, vol. 19, no. 1, pp. 51-57, 2003.

[7] G. Cimador, P. Prestifilippo, "An attractive new converter topology for $\mathrm{AC} / \mathrm{DC}, \mathrm{DC} / \mathrm{DC} \& \mathrm{DC} / \mathrm{AC}$ power conversion", in Proc. of INTELEC '90, vol. , no. , pp. 597-604, 1990.

[8] M. Nagao, K. Harada, "Power flow of photovoltaic system using buck-boost PWM power inverter", in Proc. of IEEE PEDS'97, vol. 1, no. , pp. 144-149, 1997.

[9] N. Vázquez, C. Hernández, E. Rodríguez, J. Álvarez, J. Arau, "Study And Implementation Of The Passive-based Control Law For The Boost Inverter", Revista Eletrônica de Potência (SOBRAEP), vol.10, no.1, pp. 31-37, June 2005.

[10]R.L. Cardoso, I. Barbi, "New bi-directional DC-AC converters with high frequency isolation", in Proc. of ISSCS 2005, vol. 2, no. , pp. 593-596, 2005.

[11]P.S.G. Giacomini, L.C.S. Marques, M. Mezaroba, "Digital Sliding Mode Controlled Three-phase Boost Inverter Implemented In A Dsc", Revista Eletrônica de Potência (SOBRAEP), vol.13, no.3, pp. 155-162, August 2008.

[12]D. Chen, "Novel Current-Mode AC/AC Converters With High-Frequency AC Link", IEEE Transactions on Industrial Electronics, vol.55, no.1, pp.30-37, January 2008.

[13]A. Beristáin, J. Bordonau, A. Gilabert, G. Velasco, "Synthesis and modulation of a single phase dc/ac converter with high frequency isolation in photovoltaic energy applications", in Proc. of IEEE PESC'03, vol. 3, no., pp. 1191-1196, 2003.

[14]Z. Ye, P.K. Jain, P.C. Sen, "A Two-Stage Resonant Inverter With Control of the Phase Angle and Magnitude of the Output Voltage", IEEE Transactions on Industrial Electronics, vol.54, no.5, pp.2797-2812, October 2007.

[15] S.B. Kjær, F. Blaabjerg, "Design optimization of a single phase inverter for photovoltaic applications", in Proc. of IEEE PESC'03, vol. 3, no. , pp. 1183-1190, 2003.

[16] S. Funabiki, T. Tanaka, T. Nishi, "A new buck-boostoperation based sinusoidal inverter circuit", in Proc. of IEEE PESC'02, vol. , no. , pp. 1624-1629, 2002.

[17]H. Ertl, J.W. Kolar, F.C. Zach, "A novel multicell DCAC converter for applications in renewable energy systems", IEEE Transactions on Industrial Electronics, vol.49, no.5, pp. 1048-1057, October 2002.

[18] T. Boutot, L. Chang, "Development of a single-phase inverter for small wind turbines", in Proc. of IEEE Electrical and Computer Engineering Canadian Conf. (CCECE'98), vol. 1, no. , pp. 305-308, 1998.

[19]Z. Yang, P.C. Sen, "A novel switch-mode dc-to-ac inverter with nonlinear robust control", IEEE
Transactions on Industrial Electronics, vol. 45, no. 4, pp. 602-608, August 1998.

[20] S. Saha, V.P. Sundarsingh, "Novel grid-connected photovoltaic inverter", Proc. of Inst. Elect. Eng., vol. 143, no. 2, pp. 219-224, 1996.

\section{BIOGRAPHIES}

Carlos Elmano de Alencar e Silva, was born in Fortaleza, Ceará, Brazil, on 1981. He received B. S. and M. Sc. degrees in Electrical Engineering from Federal University of Ceará, Brazil, on 2004 and 2007, respectively. Currently, he is a Dr. student in the Federal University of Ceará. His interest areas include ac-dc conversion with high power factor, dc-ac conversion and renewable energy applications. M.Sc. Carlos Elmano is a SOBRAEP member, since 2006.

Demercil de Souza Oliveira Júnior, was born in Santos, São Paulo, Brazil, in 1974. He received the BSc and MSc degrees in electrical engineering from the Federal University of Uberlândia, Brazil, in 1999 and 2001, respectively, and the Dr. degree from the Federal University of Santa Catarina, Brazil, in 2004. Currently, he is a researcher in the Group of Power Processing and Control in the Federal University of Ceará. His interest areas include DC/DC conversion, soft commutation and renewable energy applications. Dr. Demercil is a member of the SOBRAEP.

Herminio Miguel de Oliveira Filho, was born in Taguatinga, Distrito Federal, Brazil, on 1983. He received the B. Sc. degree in Electrical Engineering from the Federal University of Ceará, Brazil, in 2007. Currently, he is researcher engineer and $\mathrm{M}$. Sc. student in the Group of Energy Processing and Control in the Federal University of Ceará. His interest areas include control applications in power electronics, dc-dc conversion, and renewable energy applications. Since 2008, B. Sc. Herminio is a SOBRAEP member.

Fernando Luiz Marcelo Antunes, he received the B.Sc. degree in Electrical Engineering from Federal University of Ceará-Brazil in 1978, and the B.Sc. degree in Business and Administration from the State University of Ceará-Brazil in 1983. In 1980 he received the MSc degree from the University of São Paulo (Brazil), and in 1991 the $\mathrm{PhD}$ degree from Loughborough University of Technology United Kingdom which research project was in the field of power electronics and machine drives. He is a senior lecturer at Federal University of Ceará (Brazil) where coordinates the power electronics group. His research fields include multilevel converters, inverters and their application to renewable energy. He is the President of the Brazilian Power Electronics Society - SOBRAEP until December of 2011, and member of the Power Electronics Society of IEEE. 